\title{
Methods of determining the optimal project of reconstruction of The Petrovsky Dock in Kronstadt
}

\author{
Marina Romanovich ${ }^{1}$ and Anna Vilinskaya ${ }^{2, \text { a }}$ \\ 1 State unitary enterprise "Municipal government of inventory and assessment of real estate", Russia, 191104, St. \\ Petersburg, Belinskogo St., 13 \\ 2 Peter the Great Saint-Petersburg Polytechnic University, Russia, 195251, St. Petersburg, Polytechnicheskaya St., \\ 29
}

\begin{abstract}
Today in Russia there are many historical monuments, which are in a derelict and not the operational state. So, this is actual question about their reconstruction with preservation of historical significance, with current technology, and innovation. One of these abandoned objects is The Petrovsky Dock in Kronstadt. Priority idea of its reconstruction it is museum. The Russian and foreign experience in development of the modern sea museums is analysed. In article the existing options of reconstruction of Dock are considered. The method of calculation of total optimality project coefficient of reconstruction is offered. Survey of experts showing what functions are most interesting to the museum is conducted. As a result, we determine the optimal reconstruction project of Dock with unique functionality.
\end{abstract}

\section{Introduction}

Kronstadt - naval capital of Russia. There are the unique marine structures, historical and cultural monuments. Unfortunately, not all structures have survived to our time, some are in a derelict state, for example, Petrovsky Dock, an object of cultural heritage of federal importance.

The Petrovasky Dock - In the 18th century, it was the first dry dock in Russia, designed by Peter the Great. Dock was intended to repair the underwater parts of ships and vessels. It was a grand structure. Over time, Dock stopped using for its intended purpose, up to 2008 part of the Petrovsky Dock was used for repair of ships, but now it is not used and is in a derelict state.

In 2011, Petrovsky Dock was transferred to the ownership of St. Petersburg and was transmitted to the administration of Kronstadt district. With the view of restoration with preservation the historical and cultural features, with adaptation for modern purposes and museum like unique monument, the Administration is developing options of involving the object in economic circulation.

For consideration of the constantly offered different options for Reconstruction and the use of Petrovsky Dock. But so far no project is not implemented. In order to find the best reconstruction project it's necessary to analyze the proposed options, compare all pluses and minuses, as well as refer to successful projects both abroad and in Russia. So, to collect a complete set of information needed for a successful reconstruction project of The Petrovsky Dock.

\footnotetext{
${ }^{a}$ Corresponding author : willi-ann@yandex.ru
} 


\subsection{Literature review}

Since Petrovsky Dock building of the 18th century, it is most often mentioned in the literature devoted to the history of Kronstadt. For example, there is N. Durov's article [1], which is fully dedicated to Peter the Great Canal. F.A. Timofeevsky in his brief historical essay [2] not only tells the story of Peter's building docks and canals, but also shows a detailed plan of Kronstadt with an indication of the southern coast in 1723 and designed by Peter the Great harbors and channels. In N.A. Rykachev's article "Kronstadt old" [3] there is a separate chapter "Channel description", which described in detail the structure and the materials used in the construction of a cross-channel. The historical notes S.I. Elagina and A. Treskina [4-5] there you can also find information about construction of the Petrovsky canal. And other writers, historians have not left such a great facility without attention [6-11].

\subsection{Problem statement}

The purposes of article are:

1. An overview of the Russian and foreign experience in the field of modern museums that popularizing maritime culture;

2. Analysis and comparison of the already proposed reconstruction projects and the use of The Petrovsky Dock;

3. Determination of criteria that show the degree of success and acceptability of the reconstruction project Petrovsky Dock;

4. Choosing the best reconstruction option, taking into account the analysis and preservation of the historic value of the monument.

\section{The review of the existing sea museums}

In Russia, a lot of naval museums, but the biggest of them is located in St. Petersburg - Central Naval Museum. This is one of the oldest museums in Russia and one of the largest maritime museums in the world. In 2013 the museum moved to a renovated complex Kryukov (Marine) barracks, but, despite this, the museum didn't become modern. In our modern times visiting museums is the most interesting for people, where in addition to the study of museum exhibits can spend time interactively, immerse themselves in some of the periods of history, to do something with their own hands, to feel part of the story that keeps the museum.

From foreign experience [15-22], for example, Maritime Centre "Vellamo" in Kotka (Finland). It is a multifunctional complex that includes several museums. In addition, there is a separate information center (books, magazines, video and audio materials, pictures, and more). The museum used 3D-simulator, allowing visitors to make a virtual dive to the "Frau Maria" on the bottom. On the roof of the building maritime center is a viewing platform.

In Portsmouth (UK) is a maritime museum - Mary Rose Museum. The ship, had lain on the seabed more than four years, was raised in 1982 and was built around it the historical museum, which tells of an entire era of British history. This is really a high-tech museum, because there is the biggest museum showcase in the world. The museum building is also unique, it has the form of jewelry box, inside which is itself the renovated flagship and more than 19 thousand artifacts raised with him.

An interesting museum is located in Stockholm (Sweden) "Vasa" Museum. The museum opened in 1990 around the Swedish "Vasa» warship that sank at the entrance to the bay of Stockholm in 1628. The building allows you to inspect the hull of a wooden ship from all sides, as well as to get some room. The museum has a cinema where is shown a film about the Vasa on sixteen languages.

The modern "living" museum is Lennusadam Maritime Museum in Estonia - one of the biggest museums in the country, located in Tallinn. The museum expositions are located in three-dimensional space. In addition, the museum has a restaurant and a shop MARU, cinemas, simulators, children's area and a lot of other interesting things. There is also an outdoor roof terrace with a beautiful view of the passenger port, the city center and the Old Town. Comparing the Russian and foreign experience, 
we can say that Russia doesn't have enough good, interesting and modern maritime museum. Kronstadt - as the sea capital of Russia, a great place to create such a museum. A Petrovsky Dock can be really high-tech, multi-functional museum complex [23-26].

\section{Data description and methology}

In 2011, a competition was announced for the best reconstruction project of Petrovsky Dock, but none of them has been implemented. Offers a variety of construction companies for the reconstruction of Dock also didn't find its real application.

Consider and compare all renovation options previously proposed and use of Dock Peter the Great.

Table 1. Comparative characteristics of projects of reconstruction The Petrovsky Dock.

\begin{tabular}{|c|c|c|c|c|c|c|}
\hline № & 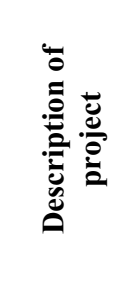 & 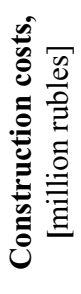 & 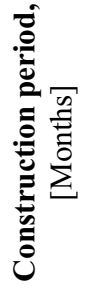 & Functions & Pluses & Minuses \\
\hline 1 & $\begin{array}{l}\text { Floating } \\
\text { fountain } \\
\text { complex }\end{array}$ & 500 & 12 & $\begin{array}{l}\text { 1. Fountain } \\
\text { 2. Concert hall } \\
\text { 3. Beautification } \\
\text { the waterfront pool } \\
\text { 4. Overview ter- } \\
\text { races }\end{array}$ & $\begin{array}{l}\text { - Strengthening the } \\
\text { attractiveness of the } \\
\text { city as a tourist } \\
\text { center } \\
\text { - Concert hall } \\
\text { - Panoramic view }\end{array}$ & $\begin{array}{l}\text { - Use only as a concert } \\
\text { hall } \\
\text { - Focus more on tourists } \\
\text { - Not saved historical } \\
\text { value } \\
\text { - Not attractive to the } \\
\text { local people, and espe- } \\
\text { cially for tourists (in } \\
\text { terms of functionality) }\end{array}$ \\
\hline 2 & $\begin{array}{c}\text { The park } \\
\text { area }\end{array}$ & 150 & 10 & $\begin{array}{l}\text { 1. Walking and } \\
\text { cycling paths } \\
\text { 2. City Park }\end{array}$ & $\begin{array}{l}\text { - Place for walks } \\
\text { - Promotion of } \\
\text { healthy lifestyles } \\
\text { - Clean air }\end{array}$ & $\begin{array}{l}\text { - Not saved historical } \\
\text { value } \\
\text { - Seasonality (in will } \\
\text { not fall and winter a } \\
\text { popular place) } \\
\text { - No income }\end{array}$ \\
\hline 3 & $\begin{array}{l}\text { The crea- } \\
\text { tive space }\end{array}$ & 275 & 20 & $\begin{array}{l}\text { 1. Shops } \\
\text { 2. Restaurants } \\
\text { 3. Offices } \\
\text { 4. Galleries } \\
\text { 5. Hostels } \\
\text { 6. The loft housing } \\
\text { 7. City Park }\end{array}$ & $\begin{array}{l}\text { - A large number of } \\
\text { services } \\
\text { - Place for walks } \\
\text { - Multifunctionality }\end{array}$ & $\begin{array}{l}\text { - Not saved historical } \\
\text { value } \\
\text { - Not attractive to the } \\
\text { tourists }\end{array}$ \\
\hline
\end{tabular}




\begin{tabular}{|c|c|c|c|c|c|c|}
\hline 4 & $\begin{array}{l}\text { The re- } \\
\text { construc- } \\
\text { tion- } \\
\text { conserva- } \\
\text { tion }\end{array}$ & 290 & 11 & $\begin{array}{l}\text { 1. Installation of } \\
\text { the vessel, with } \\
\text { restaurant and mu- } \\
\text { seum exposition } \\
\text { 2. Performance } \\
\text { 3. Reconstruction } \\
\text { of craft workshops }\end{array}$ & $\begin{array}{l}\text { - Preservation a } \\
\text { cultural monument } \\
\text { - Its transformation } \\
\text { into a commercially } \\
\text { successful project } \\
\text { - Re-creation histor- } \\
\text { ical atmosphere }\end{array}$ & $\begin{array}{l}\text { - A little functional } \\
\text { - Not enough modern } \\
\text { technologies }\end{array}$ \\
\hline 5 & $\begin{array}{l}\text { Indoor } \\
\text { Museum } \\
\text { of Un- } \\
\text { derwater } \\
\text { Archaeol- } \\
\text { ogy }\end{array}$ & 130 & 18 & $\begin{array}{l}\text { 1. Demonstration } \\
\text { of the ships in the } \\
\text { water through the } \\
\text { glass } \\
\text { 2. Training pool } \\
\text { 3. Exhibition and } \\
\text { conference Hall } \\
\text { 4. Restoration } \\
\text { workshops } \\
\text { 5. Office and aux- } \\
\text { iliary rooms }\end{array}$ & $\begin{array}{l}\text { - Combining build- } \\
\text { ings in Marine glo- } \\
\text { ry's historical com- } \\
\text { plex } \\
\text { - income from } \\
\text { diving } \\
\text { - Multifunctionality }\end{array}$ & $\begin{array}{l}\text { - glass sarcophagus } \\
\text { - Not saved historical } \\
\text { value }\end{array}$ \\
\hline 6 & $\begin{array}{l}\text { The Air- } \\
\text { ship }\end{array}$ & 210 & 10 & 1. Airship & $\begin{array}{l}\text { - Airship - a new } \\
\text { symbol of Kronstadt }\end{array}$ & $\begin{array}{l}\text { - dome of the adminis- } \\
\text { trative building resem- } \\
\text { bles the silhouette of the } \\
\text { dome of the Naval Ca- } \\
\text { thedral } \\
\text { - Not saved historical } \\
\text { value }\end{array}$ \\
\hline 7 & $\begin{array}{l}\text { Multi- } \\
\text { functional } \\
\text { complex }\end{array}$ & 395 & 18 & $\begin{array}{l}\text { 1. Exhibition of } \\
\text { warships of various } \\
\text { types } \\
\text { 2. Commercial and } \\
\text { entertainment area } \\
\text { 3. The objects of } \\
\text { public catering } \\
\text { 4. Warehouses - } \\
\text { gallery and official- } \\
\text { ly-business zone }\end{array}$ & $\begin{array}{l}\text { - Multifunctionality } \\
\text { - Income from ser- } \\
\text { vices }\end{array}$ & $\begin{array}{l}\text { - Not preserved unique } \\
\text { set of hydraulic and } \\
\text { urban landscape at a } \\
\text { location nearby }\end{array}$ \\
\hline 8 & $\begin{array}{l}\text { Building } \\
\text { in the } \\
\text { form of } \\
\text { nuclear } \\
\text { submarine } \\
\text { "Ty- } \\
\text { phoon" }\end{array}$ & 255 & 15 & $\begin{array}{l}\text { 1. Museum, exhi- } \\
\text { bition } \\
\text { 2. Restaurant with } \\
\text { a rotating figure of } \\
\text { St. Andrew on the } \\
\text { roof } \\
\text { 3. Shops }\end{array}$ & $\begin{array}{l}\text { - Multifunctionality } \\
\text { - Income from ser- } \\
\text { vices }\end{array}$ & $\begin{array}{l}\text { - Not saved historical } \\
\text { value,because in } \\
\text { Kronstadt never built } \\
\text { submarines }\end{array}$ \\
\hline
\end{tabular}




\begin{tabular}{|c|c|c|c|l|l|l|}
\hline 9 & $\begin{array}{c}\text { Multi- } \\
\text { functional } \\
\text { center }\end{array}$ & 280 & 16 & $\begin{array}{l}\text { 1. Museum } \\
\text { 2. Diving Centre } \\
\text { 3. Sea Club for } \\
\text { children }\end{array}$ & $\begin{array}{l}\text { - Multifunctionality } \\
\text { - Income from ser- } \\
\text { vices }\end{array}$ & $\begin{array}{l}\text { - Not saved historical } \\
\text { value }\end{array}$ \\
\hline 10 & $\begin{array}{l}\text { Museum } \\
\text { complex }\end{array}$ & 620 & 19 & $\begin{array}{l}\text { 1. Underwater } \\
\text { excursions } \\
\text { 2. Exposition of } \\
\text { real ships } \\
\text { 3. Diving Centre }\end{array}$ & $\begin{array}{l}\text { - Preserving history } \\
\text { - Multifunctionality }\end{array}$ & - relatively expensive \\
\hline
\end{tabular}

\subsection{Definition of the optimum project}

To conduct a comprehensive assessment of each of the above applications projects, we calculate weights for each project, using widely applicable-employed in the construction method of expert evaluations [20]. Each of the ten projects evaluated by five experts on a scale from 1 to 10. Matrix of weighted estimates constructed after affixing estimates [21, 22], presented in Table 2.

Table 2. Matrix of weighted estimates.

\begin{tabular}{|c|c|c|c|c|c|c|c|c|c|c|c|}
\hline \multirow{2}{*}{ Experts } & \multicolumn{9}{|c|}{ Coefficients of optimality } & \multirow{2}{*}{ Total score } \\
\cline { 2 - 12 } & 1 & 2 & 3 & 4 & 5 & 6 & 7 & 8 & 9 & 10 & $\sum_{k=1}^{m} h_{i k}$ \\
\hline 1 & 3 & 4 & 4 & 5 & 5 & 4 & 4 & 5 & 5 & 5 & 44 \\
\hline 2 & 4 & 3 & 1 & 4 & 5 & 2 & 2 & 3 & 3 & 4 & 31 \\
\hline 3 & 4 & 5 & 2 & 3 & 4 & 4 & 3 & 4 & 5 & 5 & 39 \\
\hline 4 & 3 & 3 & 2 & 5 & 5 & 4 & 5 & 4 & 4 & 5 & 40 \\
\hline 5 & 1 & 3 & 0 & 5 & 3 & 0 & 4 & 0 & 2 & 0 & 18 \\
\hline
\end{tabular}

Next, the total score is determined for each criterion, obtained by summing the values of each column of the matrix [21], presented in Table 3.

Table 3. Matrix of weighted estimates.

\begin{tabular}{|c|c|c|c|c|c|c|c|c|c|c|c|}
\hline \multirow[b]{2}{*}{ Experts } & \multicolumn{10}{|c|}{ Coefficients of optimality } & \multirow{2}{*}{$\begin{array}{l}\text { Total } \\
\text { score } \\
\sum_{k=1}^{m} h_{i k}\end{array}$} \\
\hline & 1 & 2 & 3 & 4 & 5 & 6 & 7 & 8 & 9 & 10 & \\
\hline 1 & $3 / 44$ & $4 / 44$ & $4 / 44$ & $5 / 44$ & $5 / 44$ & $4 / 44$ & $4 / 44$ & $5 / 44$ & $5 / 44$ & $5 / 44$ & 44 \\
\hline 2 & $4 / 31$ & $3 / 31$ & $1 / 31$ & $4 / 31$ & $5 / 31$ & $2 / 31$ & $2 / 31$ & $3 / 31$ & $3 / 31$ & $4 / 31$ & 31 \\
\hline 3 & $4 / 39$ & $5 / 39$ & $2 / 39$ & $3 / 39$ & $4 / 39$ & $4 / 39$ & $3 / 39$ & $4 / 39$ & $5 / 39$ & $5 / 39$ & 39 \\
\hline 4 & $3 / 40$ & $3 / 40$ & $2 / 40$ & $5 / 40$ & $5 / 40$ & $4 / 40$ & $5 / 40$ & $4 / 40$ & $4 / 40$ & $5 / 40$ & 40 \\
\hline 5 & $1 / 18$ & $3 / 18$ & $0 / 18$ & $5 / 18$ & $3 / 18$ & $0 / 18$ & $4 / 18$ & $0 / 18$ & $2 / 18$ & $0 / 18$ & 18 \\
\hline $\begin{array}{c}\text { Total } \\
\text { mark } r_{i}\end{array}$ & 0,43 & 0,56 & 0,22 & 0,72 & 0,67 & 0,36 & 0,58 & 0,41 & 0,57 & 0,50 & \\
\hline
\end{tabular}

The values of weighting coefficients calculated by the formula (1), at the same time the condition presented in a formula 2 has to be satisfied [21]: 


$$
\begin{gathered}
\sigma_{i}=\frac{r_{i}}{\sum_{i=1}^{m} r_{i}} \\
\sum_{i=1}^{n} \sigma_{i}=1
\end{gathered}
$$

$$
\sum_{i=1}^{m} r_{i}=0,43+0,56+0,22+0,72+0,67+0,36+0,58+0,41+0,57+0,50=5,02
$$

The weighting coefficients for each project are presented in Table 4.

To determine the total optimality project coefficient following indicators have been introduced:

$\boldsymbol{K}_{\text {cost }}$ - construction cost coefficient, calculated based on the average cost of construction $=313,5$ million rubles, corresponding to 5 points on 10-point scale;

$\boldsymbol{K}_{\text {period }}$ - construction period coefficient, calculated based on the average period of construction $=$ 14,9 months corresponding to 5 points on 10 -point scale.

$\boldsymbol{K}_{\text {multi }}-$ multifunctionality coefficient corresponds to the number of functions, which performs one or another product (table 1).

The total optimality project coefficient calculated by the formula (3):

$$
\sum K_{\text {optimal }}=\left(K_{\text {cost }}+K_{\text {period }}+K_{\text {multi }}\right) \times K_{\text {weight }}
$$

The values of all coefficients are given in Table 4 .

Table 4. The calculation of the total optimality project coefficient.

\begin{tabular}{|c|c|c|c|c|c|}
\hline № & $\boldsymbol{K}_{\text {cost }}$ & $\boldsymbol{K}_{\text {period }}$ & $\boldsymbol{K}_{\text {multi }}$ & $\boldsymbol{K}_{\text {weight }}$ & $\sum_{\text {Koptimal }}$ \\
\hline $\mathbf{1}$ & $\mathbf{2}$ & $\mathbf{3}$ & $\mathbf{4}$ & $\mathbf{5}$ & $\mathbf{6}$ \\
\hline 1 & 7,98 & 4,03 & 4,00 & 0,09 & 1,44 \\
\hline 3 & 2,39 & 3,36 & 2,00 & 0,11 & 0,85 \\
\hline 4 & 4,39 & 6,71 & 7,00 & 0,04 & 0,72 \\
\hline $\mathbf{5}$ & 4,63 & 3,69 & 3,00 & 0,14 & 1,58 \\
\hline 6 & $\mathbf{2 , 0 7}$ & $\mathbf{6 , 0 4}$ & $\mathbf{5 , 0 0}$ & $\mathbf{0 , 1 3}$ & $\mathbf{1 , 7 0}$ \\
\hline $\mathbf{7}$ & 3,35 & 3,36 & 1,00 & 0,07 & 0,54 \\
\hline 8 & $\mathbf{6 , 3 0}$ & $\mathbf{6 , 0 4}$ & $\mathbf{4 , 0 0}$ & $\mathbf{0 , 1 2}$ & $\mathbf{1 , 9 6}$ \\
\hline 9 & 4,07 & 5,03 & 3,00 & 0,08 & 0,97 \\
\hline $\mathbf{1 0}$ & 4,46 & 5,37 & 3,00 & 0,11 & 1,41 \\
\hline
\end{tabular}

\subsection{Topical museum functions}

For definition of optimum functions of the museum 7 experts have been interrogated. The list of functions for the museum has been made. Experts had to choose the most pleasant options. Results are presented in Table 5. 
Table 5. Determination of the optimal project functions.

\begin{tabular}{|c|c|c|c|c|c|c|c|c|c|}
\hline & & \multicolumn{8}{|c|}{ Experts } \\
\hline № & Function name & 1 & 2 & 3 & 4 & 5 & 6 & 7 & Kopinion \\
\hline 1 & Fountain & & & & & & & & 0 \\
\hline 2 & Concert hall & & & & & & & & 0 \\
\hline 3 & Viewing platforms & + & + & + & + & + & & + & 6 \\
\hline 4 & Shops & & & + & & & & & 1 \\
\hline 5 & Restaurants & + & + & & & & & + & 3 \\
\hline 6 & Offices & + & & & & & & & 1 \\
\hline 7 & Galleries & & & + & & & & & 1 \\
\hline 8 & Exposition of real ships & + & + & + & + & & + & + & 6 \\
\hline 9 & Craft workshops & & + & & + & & + & & 3 \\
\hline 10 & Aquariums & + & + & & & + & + & + & 5 \\
\hline 11 & Airship & & + & & & & & & 1 \\
\hline 12 & Sea Club (for children) & & + & + & + & + & & & 4 \\
\hline 13 & Diving & + & + & & & & & + & 3 \\
\hline 14 & Underwater excursions & & + & & & & & & 1 \\
\hline 15 & Quest (on the marine theme) & + & & + & + & + & & + & 5 \\
\hline 16 & $\begin{array}{l}\text { The visualization system, interactive (visi- } \\
\text { tors can lay on the levels, rotate, zoom in } \\
\text { and almost make the cut image and reveal } \\
\text { hidden details of exhibits) }\end{array}$ & + & + & + & + & + & + & + & 7 \\
\hline 17 & Multimedia books (living books) & + & & & + & & + & + & 4 \\
\hline 18 & $\begin{array}{c}\text { Excursions from St. Petersburg (and other } \\
\text { cities) }\end{array}$ & + & & & & & & + & 2 \\
\hline
\end{tabular}

\section{Conclusion}

After review and comparison of the Russian and foreign experience in the creation of maritime museums, we can conclude that Russia needs an interesting and cotemporary Maritime Museum. As the sea capital Kronstadt is a great place to create such a museum. As a variant - the reconstruction of Petrovsky Dock for high-tech museum complex.

It was previously suggested options for the restoration of Petrovsky Dock. In the course of this work were analyzed polls, the results of which determined the most optimal, according to experts, projects. As a result of the leading position is occupied Multifunctional complex (project №7 table 1), which includes an outdoor exhibition of military vehicles of different types, shopping and entertainment area, catering facilities, parkgauzy gallery and officially-business zone, construction cost 395 million rubles, the construction period - 18 months. Construction costs slightly higher than the average figure for all projects, if we add the functional, based on the interests of the experts (table 5), the cost increase that immediately makes the project not optimal.

In second place The museum complex (project №10 table 1), which offers excursions under water, exposure of real ships, diving center. Construction period 19 months, the cost - 620 million rubles. Minus of this project - relatively expensive, which immediately raises the question of its implementa- 
tion. And on the third place Indoor Museum of Underwater Archaeology (project №5 table 1), which is a demonstration the ships in the water through the glass, a training pool, exhibition and conference halls, restoration workshops, office and auxiliary premises. Construction period - 18 months, the cost - 130 million rubles. Even if you increase the functional components of the project, the cost of the construction will not exceed the average for projects.

Comparing and analyzing these three projects, we conclude that the last project is optimal for the reconstruction of Petrovsky Dock. It is a modern Indoor Museum of Underwater Archaeology, where you can see the exposure of real ships in the water through the glass, scuba diving training in the pool, spend some time in the restoration workshops, as well as to conduct business meetings in the exhibition and conference halls, offices and auxiliary rooms. Based on the interest of visitors to the innovative technologies, interactive visualization system is ideal for the exhibition, visitors can lay out on the levels, rotate, zoom in and almost make the cut image and reveal hidden details of artifacts. Today the quests become more and more topical on the marine theme could be especially interesting. Finally, the viewing platforms to enjoy the view around Petrovsky Dock, because the location is really unique.

\section{References}

1. N. Durov Materialy dlya istorii stroitel'nogo dela v Rossii (Saint-Petersburg, Spb, 1862).

2. F. A. Timofeevskii Kratkiy istoricheskiy ocherk dvuhsotletiya goroda Kronshtadta (Kronshtadt, Spb, 1913).

3. N. A. Ryikachyov Kronshtadtskaya starina (Kronshtadtskiy vestnik, Kronshtadt, 1885).

4. S. I. Elagin Nachalo Kronshtadta (Kronshtadtskiy vestnik, Kronshtadt, 1866).

5. A. Treskin Istoricheskiy ocherk Kronshtadta (Kronshtadtskiy vestnik, Kronshtadt, 1862).

6. A. V. Shelov Istoricheskiy ocherk kreposti Kronshtadt (Kotlin, Spb, 1904).

7. P. I. Shalikov Puteshestvie v Kronshtadt 1805 goda (Moscow, 1817).

8. A. A. Inostrantsev Geologicheskoe stroenie ostrova Kotlina (Kronshtadt, Spb, 1912).

9. P. N. Stolpyanskiy Istoriko-obschestvennyiy putevoditel po Kronshtadtu (Petrograd, Spb, 1923).

10. L. I. Tokareva Ekskursiya po gorodu s Lidiey Tokarevoy $i$ «Kronshtadtskim vestnikom» (Kronshtadtskiy vestnik, Kronshtadt, 2004).

11. M. A. Shlendova Oni rodilis v Kronshtadte (MKS, Spb, 2004).

12. P. Karon, InfoWorld, 17(45), 68 (1995).

13. British Heritage, 21(3), 13-14 (2000).

14. S. Kenderdine, Archives and Museum Informatics, 12(1), 17-38 (1998).

15. National Geographic, No 179(5), 1 (1991).

16. L.A. Kvarning, Scientific American, 269(4), 84-91 (1993).

17. M. Mändel, O. Orro, Construction History, 27, 65-85 (2012).

18. P.B. Jones, Architectural Review, 213(1271), 48 (2003).

19. J. Weirick, Architecture Australia, 4, 14-18 (2001).

20. M. A. Romanovich T. L. Simankina, D. P. Ilchenko, Promyishlennoe i grazhdanskoe stroitelstvo, 5, 73-77 (2015).

21. O. A . Grebneva Teoriya prinyatiya resheniy: Ucheb. Posobie (IrGTU, Irkutsk, 2012).

22. V. V. Fedoseev, A.N.Garmash, ,D. M. Dayitbegov Ekonomiko-matematicheskie meto-dyi $i$ prikladnyie modeli (UNITI, Moscow, 1999)

23. N. Pavličić, M. Perazić, D. Durić-Jocić, M. Knežević, Journal of Applied Engineering Science, 12 (1), 11-18 (2014)

24. M. Ćetković, D. Vuksanović, M. Knežević, T. Samardžioska, M. Cvetkovska, Journal of Applied Engineering Science, 10 (1), 31-36 (2012)

25. J. Cetkovic, M. Knežević, I. Vujovic, J. Cerovic, Technics Technologies Education Management, 7 (4), 1646-1654 (2012)

26. J. Ćetković, S. Rutešić, M. Zarković, M. Knežević, N. Vatin, Procedia Engineering, 117 (1), 780-790 (2015) 